\title{
Cytogenetic and molecular analysis of the Pantaneiro cattle breed
}

\author{
Érica Cunha Issa ${ }^{(1)}$, Wilham Jorge ${ }^{(2)}$ and José Robson Bezerra Sereno ${ }^{(3)}$
}

\begin{abstract}
(1)Universidade Estadual Paulista Júlio de Mesquita Filho, Campus Botucatu, Distrito de Rubião Junior, CEP 18618-000 Botucatu, SP, Brazil. E-mail: erica_issa@yahoo.com.br (2)Universidade Federal de Minas Gerais, Dep. de Biologia Geral, Av. Antônio Carlos, no 6627, Pampulha, Caixa Postal 486, CEP 31270-901 Belo Horizonte, MG, Brazil. E-mail: wiljorge@icb.ufmg.br (3)Embrapa Cerrados, BR 020, Km 18, Caixa Postal 08223, CEP 73310-970 Planaltina, DF, Brazil. E-mail: sereno@cpac.embrapa.br
\end{abstract}

\begin{abstract}
The objective of this work was to characterize Pantaneiro cattle genetically through its paternal ancestry by the morphology of the $\mathrm{Y}$ chromosome, whether submetacentric or acrocentric, as well as to identify the maternal ancestry through mitochondrial DNA. The karyotype and mitochondrial DNA of 12 bulls of Pantaneiro breed were analyzed. The Y chromosome was analyzed in lymphocyte metaphases and the mitochondrial DNA by diagnosing its haplotype (Bos taurus and Bos indicus). Among Pantaneiro animals analyzed three had a taurine (submetacentric) $Y$ and nine had a zebuine (acrocentric) $Y$ chromosome, suggesting breed contamination by Zebu cattle, once Pantaneiro is considered to be of European origin. The mitochondrial DNA was exclusively of taurine origin, indicating that the participation of zebuines in the formation of the breed occurred entirely through the paternal line.
\end{abstract}

Index terms: Bos taurus taurus, Bos taurus indicus, Y chromosome, mitochondrial DNA.

\section{Análise citogenética e molecular do bovino Pantaneiro}

\begin{abstract}
Resumo - O objetivo deste trablaho foi caracterizar geneticamente o bovino Pantaneiro por meio de sua ancestralidade paterna, pela morfologia de seu cromossomo Y, submetacêntrico ou acrocêntrico, e identificar a ancestralidade materna pelo DNA mitocondrial. O cariótipo e o DNA mitocondrial de 12 touros da raça Pantaneira foram cariotipados e analisados. O cromossomo Y foi analisado por meio das metáfases de linfócitos e o DNA mitocondrial pelo diagnóstico de seu tipo de haplótipo (Bos taurus ou Bos indicus). Entre os Pantaneiros analisados, três apresentaram Y de taurino (submetacêntrico) e nove de zebuíno (acrocêntrico), o que sugere contaminação racial por zebuínos, visto que o Pantaneiro é considerado de origem Européia. O DNA mitocondrial foi exclusivamente de taurinos, o que indica que a participação de zebuínos na formação da raça foi inteiramente de origem paterna.
\end{abstract}

Termos para indexação: Bos taurus taurus, Bos taurus indicus, cromossomo Y, DNA mitocondrial.

\section{Introduction}

The $\mathrm{Y}$ chromosome and the mitochondrial DNA (mtDNA) have some genetic properties in common: they are inherited from only one parent. The $\mathrm{Y}$ chromosome is transmitted by the sperm to the male offspring, and the mitochondrial DNA by the ovocyte to both male and female offspring. Furthermore, they undergo no recombination, except for the pseudoautosomal region of chromosome $Y$, thus being transmitted to following generations in gene blocks named haplotypes. Haplotypes remain unchanged until a mutation occurs.

According to Liu et al. (2002, 2003), haplotypes resulting from bovine $\mathrm{Y}$ microsatellite polymorphism should provide a powerful tool for studies on the origin of domestic cattle and evolution of bovid species.

The Y chromosome of the genus Bos, and particularly of the subspecies Bos taurus taurus (taurines) and Bos taurus indicus (zebuines), presents three main morphologies: submetacentric and metacentric for taurines, and acrocentric for zebuines. Moreover, differences in size of the Y chromosomes between breeds have been reported, with a variation equivalent to the difference between the $22^{\text {nd }}$ and the $26^{\text {th }}$ pairs of autosomes (Jorge, 1974).

Linnaeus' classical nomenclature distinguishes the existence of two species in the genus Bos: Bos indicus (with a hump) e Bos taurus (without a hump). However, the complete interfertility between $B$. indicus and 
B. taurus led several authors to consider both as subspecies (Epstein \& Mason, 1984). Currently, they are usually separated into two large groups, those with a hump and abundant dewlap (Bos taurus indicus), and those without these features (Bos taurus taurus). According to Serrano et al. (2004), the portuguese purebred belonged to one of three groups: Batavian (Bos taurus batavicus) represented by Barrosa and Turino breeds; Aquitanian (Bos taurus aquitanicus), represented by Galega, Arouquesa, Alentejana, Mertolenga, Algarvia and Minhota breeds; and Iberian (Bos taurus ibericus), represented by Mirandesa and Brava breeds. The origin of the Iberian Peninsula cattle, together with that of the rest of Europe, seems to be associated with Bos primigenius, the so called Aurochs (Mazza et al., 1994).

Epstein (1971) pointed out that traditionally the African breeds with a hump have been classified as Bos indicus, but that two types should be distinguished from one another: Zebu, with a thoracic hump, and Sanga (African zebu), with a cervico-thoracic hump.

The classification of African bovines into B. taurus and B. "taurindicus" by Frisch et al. (1997) was based on their karyotype, frequency of DNA markers and protein polymorphism. Boran, the eastern African Zebu, has an acrocentric $\mathrm{Y}$ chromosome that is typical for Bos indicus. Sanga breeds, from Southern Africa, have a submetacentric Y chromosome, which is typical for Bos taurus. The frequencies of four DNA markers support the hypothesis that Tuli, a South African Sanga, had a taurine ancestor, and that Boran had two ancestors: one taurus and the other indicus. Frequencies of several protein polymorphisms strongly suggest that the South African sangas have more in common with the taurines than with the Indian breeds, whereas the East African zebus are a mixture of African taurus and Asian indicus breeds. The introgression of genes in African animals is predominantly performed by the introduction of bulls. The detection of a zebu Y chromosome in the African livestock offers significant evidence of the introduction of zebuine genes into the populations of taurine cattle.

Hanotte et al. (2000) analysed 69 African bovine populations from 22 countries for a marker locus (INRA 124) of the Y chromosome. From the 984 males studied, $693(70 \%)$ and 291 (30\%) showed the indicus and taurus allele, respectively.

The Y chromosome dimorphism in bovines has been studied since 1964 . The morphologic difference between the $\mathrm{Y}$ chromosomes of the two subspecies can be attributed to a pericentric inversion (Goldammer et al., 1997; Di Meo et al., 2005). Di Meo et al. (2005), using cytogenetic and fluorescent in situ hybridization (FISH) techniques, concluded that a transposition of the centromere or a pericentric inversion occurred, which differentiated the $Y$ chromosome of $B$. taurus from that of $B$. indicus. Iannuzzi et al. (2001) found an abnormal $\mathrm{Y}$ chromosome originated from a pericentric inversion of the Yq arm (Yq11 $\rightarrow$ q12.2) through both banding and FISH mapping techniques.

At the time of the Discovery, there were no bovines in the American Continent. When this was colonized, the Spaniards and the Portuguese brought the Iberian breeds with them. Over time, these breeds evolved and adapted to local sanitary conditions, to climate, as well as to the management found in the diverse habitats here, giving rise to Brazilian naturalized breeds, also named local breed or, more generically, “crioulo” (Creole) (Egito et al., 2002).

In the late $19^{\text {th }}$ and early $20^{\text {th }}$ century, breeds considered exotic were brought to Brazil, and through absorbing crosses, they gradually caused genetic erosion and a rapid substitution of the local breeds.

Pantaneiro bovine is a valuable genetic resource, which was the basis of the cattle farming in the Pantanal region for three centuries. This breed is currently considered endangered, due to the introduction of Zebu cattle in the region over the $20^{\text {th }}$ century (Mazza et al., 1994). Empresa Brasileira de Pesquisa Agropecuária (Embrapa) through its Embrapa Pantanal, aims at preserving the remaining populations of Pantaneiro bovines.

Pantaneiro bovine, also named Cuiabano or Tucura, descends from the Spanish breeds introduced in America during the colonization process of the Plata Basin. The influence of Portuguese breeds occurred much later, from the $18^{\text {th }}$ century on, indirectly through their descendents, which had formed other breeds such as Franqueiro, Curraleiro, and others (Mazza et al., 1994), these already adapted to the Brazilian environments.

According to Mazza et al. (1994), the literature on the phenotypic characteristics of Pantaneiro bovine, from the $16^{\text {th }}$ to the $18^{\text {th }}$ centuries, is rather scarce. Publications from the $20^{\text {th }}$ century portray these animals as short of stature, with short, brown, dark and red-brown hair. The authors believe that the descriptions of the animals of the Pantanal region, made in the $20^{\text {th }}$ century, are not reliable, because in that time the crosses with other domestic and even zebuine breeds were still occurring. 
More than three centuries of adaptation to the native pastures of the flood plains of Pantanal conferred the Pantaneiro bovine with rusticity, high fertility and the ability to survive under conditions of water and food stress (Mazza et al., 1994).

According to some authors, several naturalized Brazilian breeds present Y chromosome dimorphism within the same breed (Carvalho et al., 1994; Britto \& Mello, 1999). Such dimorphism has also been found in other breeds over different countries (Xin \& Lin, 1993; Meghen et al., 1994; Jaszczak et al., 1998; Giovambattista et al., 2000).

The present work had the objective of genetically characterizing the Pantaneiro bovine and identifying the origin of its genetic material ( $\mathrm{Y}$ chromosome and mitochondrial DNA).

\section{Material and Methods}

Twelve unrelated males from the Embrapa Pantanal Nhumirim Farm, subregion of Nhecolândia, Corumbá, MS, were used to evaluate the Y chromosome and mtDNA of Pantaneiro bovine. These animals were brought from Poconé, MT, Pantanal in 1984, in order to establish the first "in situ" Conservation Nucleus of Pantaneiro bovine, located at Nhumirim Farm, Embrapa Pantanal.

Blood for lymphocyte culture was collected by venous puncture of the jugular, using $4 \mathrm{~mL}$ Vacutainer tubes with sodium heparin. For the mtDNA technique, a different anticoagulant (K3 EDTA) was used. The tubes were kept refrigerated until processing in the laboratory. Cell culture was performed using the standard technique with $4 \mathrm{~mL}$ culture medium, $1 \mathrm{~mL}$ fetal calf serum, $0.1 \mathrm{~mL}$ phytohemagglutinin and 8 drops of blood, 70-72 hours of incubation, 50 min colchicine and 20 min hypotonic ( $\mathrm{KCl} 0.075 \mathrm{M}$ ) treatment. After fixation in 3:1 methanol/ acetic acid, the material was dripped on slides, stained with Giemsa, and examined under a regular optical microscope. At least, 15 metaphases of good quality from each animal were examined and photographed using digital microphotography.

For analysis of mtDNA haplotype, DNA was extracted from $3 \mathrm{~mL}$ of blood from each animal, using the standard extraction protocol of the Human and Medical Genetics Laboratory, of the Institute of Biological Sciences of the Universidade Federal de Minas Gerais (ICB-UFMG) (Miller et al., 1988).
After DNA quantification, 100 ng DNA of each sample was used for amplification by PCR (polymerase chain reaction), using a termocycler (Genius, Techne Cambridge Limited, England), and primers sequence according to Meirelles et al. (1999). The PCR reaction mixture consisted of 10 pmol of each of the forward (5'-GCCCGAAACCAGACGAGCTAC-3') and reward (5'-TTGTATGAATGGCCGCACGAGG-3') primers; 20 mM Tris-HCl (pH 8,4); 50 mM KCl; 3.5 mM MgCl ; $600 \mathrm{mM}$ of each dGTP, dATP, dTTP and dCTP (dNTP; Gibco BRL, Life Technologies, USA), and 1.25 U Taq polymerase (Invitrogen, USA), in a final volume of $30 \mu \mathrm{L}$.

The PCR was performed using one cycle at $94^{\circ} \mathrm{C}$, during $3 \mathrm{~min}$, followed by 40 cycles, each consisting of denaturation during $45 \mathrm{~s}$ at $94^{\circ} \mathrm{C}$, annealing during $45 \mathrm{~s}$ at $58^{\circ} \mathrm{C}$, and extension during $90 \mathrm{~s}$ at $72^{\circ} \mathrm{C}$. One last cycle was performed during $10 \mathrm{~min}$ at $72^{\circ} \mathrm{C}$. A 749-bp fragment of gene 16S of the mtDNA rRNA, from both $B$. indicus and $B$. taurus haplotypes, was amplified. This fragment encompasses the region between nucleotides 1692 and 2441 of mtDNA. The amplification product was digested overnight, at $37^{\circ} \mathrm{C}$, with 5IU of HpaI, wich has one restriction site in the B. taurus mtDNA (producing two fragments), and two amplification sites in the $B$. indicus mtDNA (producing three fragments) (Meirelles et al., 1999). After digestion of the amplified mtDNA, electrophoresis was carried out in 1.2\% agarose gel, stained with ethidium bromide, and digestion products were visualized under ultraviolet light, in order to identify the mtDNA haplotype.

\section{Results and Discussion}

All animals analyzed in this study presented $2 \mathrm{n}=60$, showing that the chromosome number does not vary within the species Bos taurus. All autosomes were acrocentric, and the $\mathrm{X}$ chromosome, one of the largest in the karyotype, was submetacentric. As for the $\mathrm{Y}$ chromosome, two morphological presentations were observed: acrocentric and submetacentric.

The diploid chromosome number of bovines, both of the subspecies Bos taurus taurus and of the subspecies Bos taurus indicus, is $2 \mathrm{n}=60$, a fact known since 1931. The Y chromosome does not vary only in its morphology, regarding the position of the centromere, but it also presents variable sizes (Jorge, 1974).

Pesq. agropec. bras., Brasília, v.41, n.11, p.1609-1615, nov. 2006 
In 1999, Britto \& Mello studied the Y chromosome morphology in "Pé-duro" bulls, also known as Curraleiro. The suspicion of breed contamination by zebuine animals (Bos taurus indicus), in bovines considered to be closer to their European origin (Bos taurus ibericus), was confirmed by the detection of both chromosome types in the livestock kept at Embrapa Meio-Norte preservation nucleus. Of the animals studied, $68 \%$ had an acrocentric and $32 \%$ a submetacentric Y chromosome. Of the 12 animals of Pantaneiro breed analyzed in the present work, nine (75\%) had an acrocentric Y (Figure 1), and three (25\%) a submetacentric Y chromosome (Figure 2). The presence of a higher percentage of acrocentric $\mathrm{Y}$ chromosomes in these animals may be due to absorbing

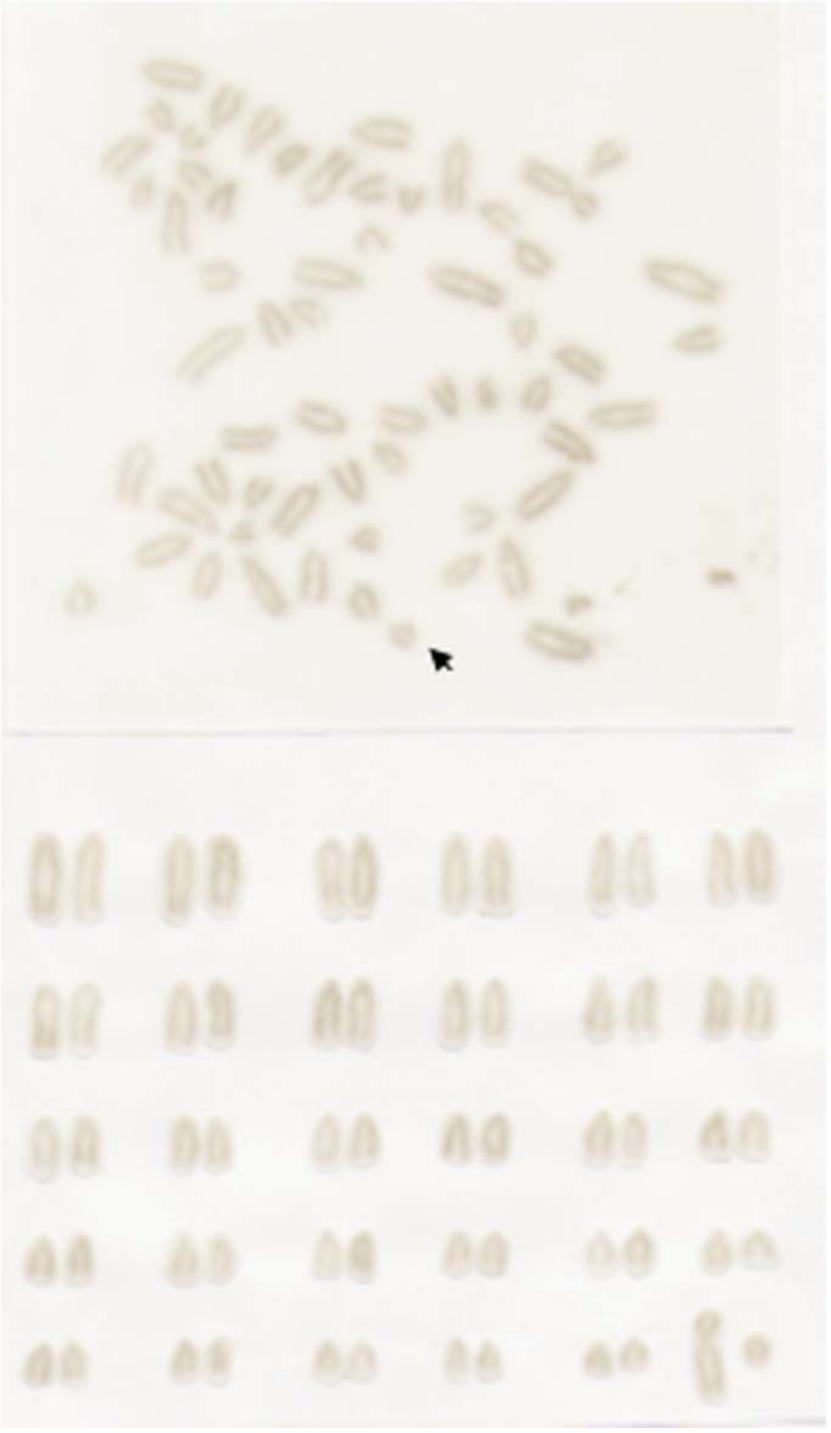

Figure 1. Karyotype of Pantaneiro cattle exhibiting an acrocentric Y chromosome, typical of Bos taurus indicus. Chromosome constitution $2 \mathrm{n}=60, \mathrm{XY}$. crosses with Zebu cattle. This dimorphism of the $\mathrm{Y}$ chromosome indicates a participation of both bovine subspecies in the formation of Pantaneiro bovine. However, considering the phenotypic characteristics of the animals with a submetacentric Y chromosome, and their European origin (Bos taurus ibericus) (Serrano et al., 2004), it seems that these animals are closer to Bos taurus taurus, therefore being the more typical representatives of the breed.

In view of the contribution of males from both subspecies to the formation of this breed, it should be considered heteromorphic, because of the presence of the two types of Y chromosomes.

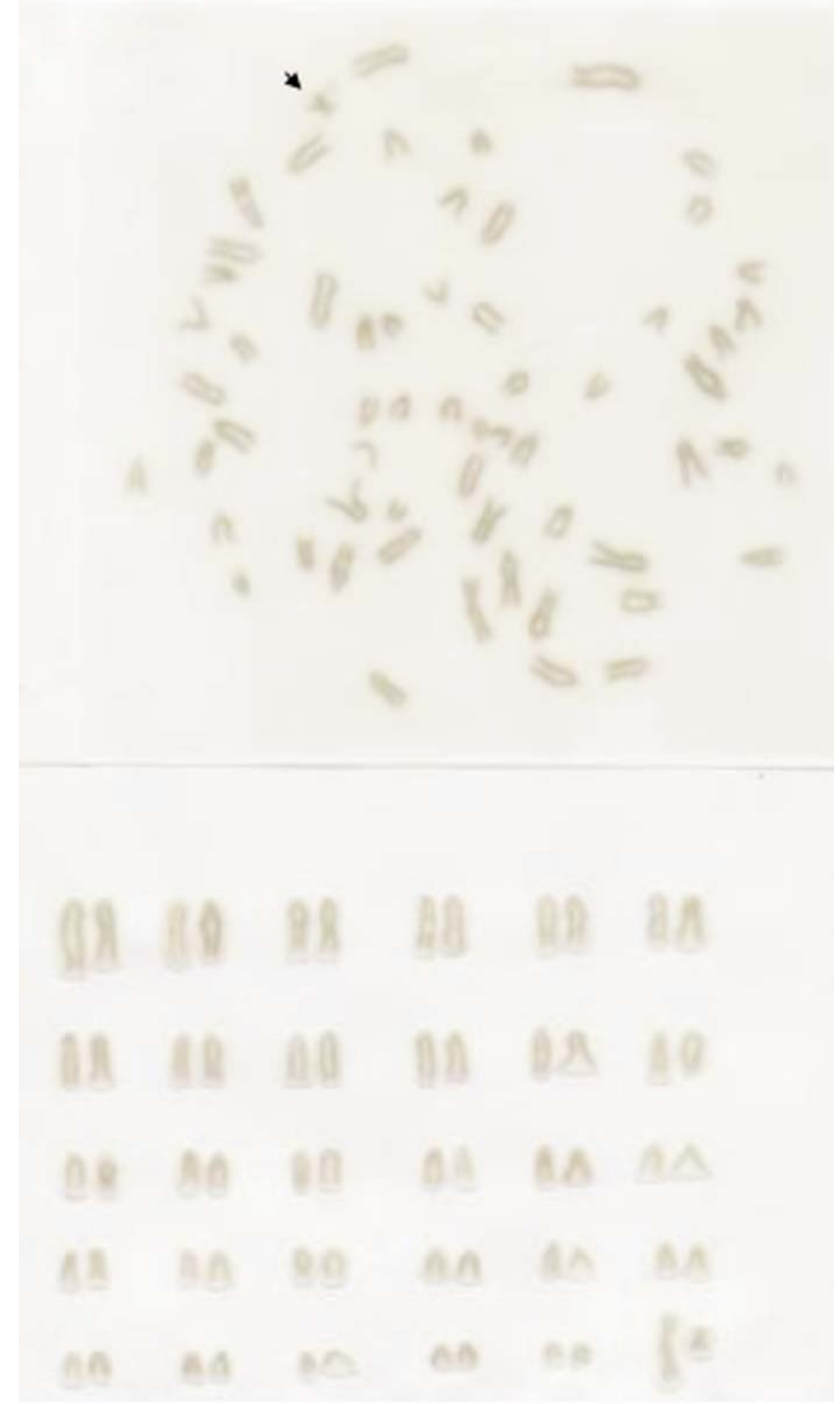

Figure 2. Karyotype of Pantaneiro cattle exhibiting a submetacentric Y chromosome, typical of Bos taurus taurus. Chromosome constitution $2 \mathrm{n}=60, \mathrm{XY}$ 
These results prove the participation of both subspecies in the formation of Pantaneiro bovine. Iberian bovine was not the only one to originate this breed. In the end of $19^{\text {th }}$ and early $20^{\text {th }}$ century, zebuine breeds, from Uberaba, MG, were introduced in the Pantanal region (Mazza et al., 1994). They gradually were incorporated into Pantaneiro livestock. Thus, crosses may have occurred between this zebuine breed and Pantaneiro, where the bulls were zebuine. If no such crosses occurred, the Iberian cattle that came to Brazil would also have had to present this chromosome Y polymorphism, which is less likely.

According to Britto (1995), the type of Y chromosome can only be said to work as an indicator of the bovine subspecies to which the animal belongs and of its sexual differentiation (testicle formation), without any influence on other phenotypic characteristics. Nevertheless, studies on the human Y chromosome have shown that microdeletions of some regions of the long arm lead to spermatogenesis disorders (Foresta et al., 2001; Ambasudhan et al., 2003).
The 12 Pantaneiro bovines analyzed here had exclusively mtDNA of taurine origin (Figure 3). This constitutes a safe indication that in the formation of this breed there was no or little participation of zebuine females. Bos taurus indicus animals used in absorbing crosses in the late $19^{\text {th }}$ century were exclusively males.

Meirelles et al. (1999), using the mtDNA polymorphism, showed evidence of the participation of females of taurine origin, in the formation of the pure American Zebu breeds. According to these authors, of the Brazilian zebuines analyzed (Nelore and Gyr), 58\% had mtDNA of taurine origin, indicating a strong influence of taurine breeds in the formation of the South American Zebu. The animals of the Brahman breed (US Zebu) presented exclusively Bos taurus taurus mtDNA, indicating that the participation of Bos taurus indicus in the formation of that breed was entirely paternal.

Watanabe et al. (1989) showed that the Philippine bovines present both types of mtDNA proving miscegenation of European and Indian cattle.

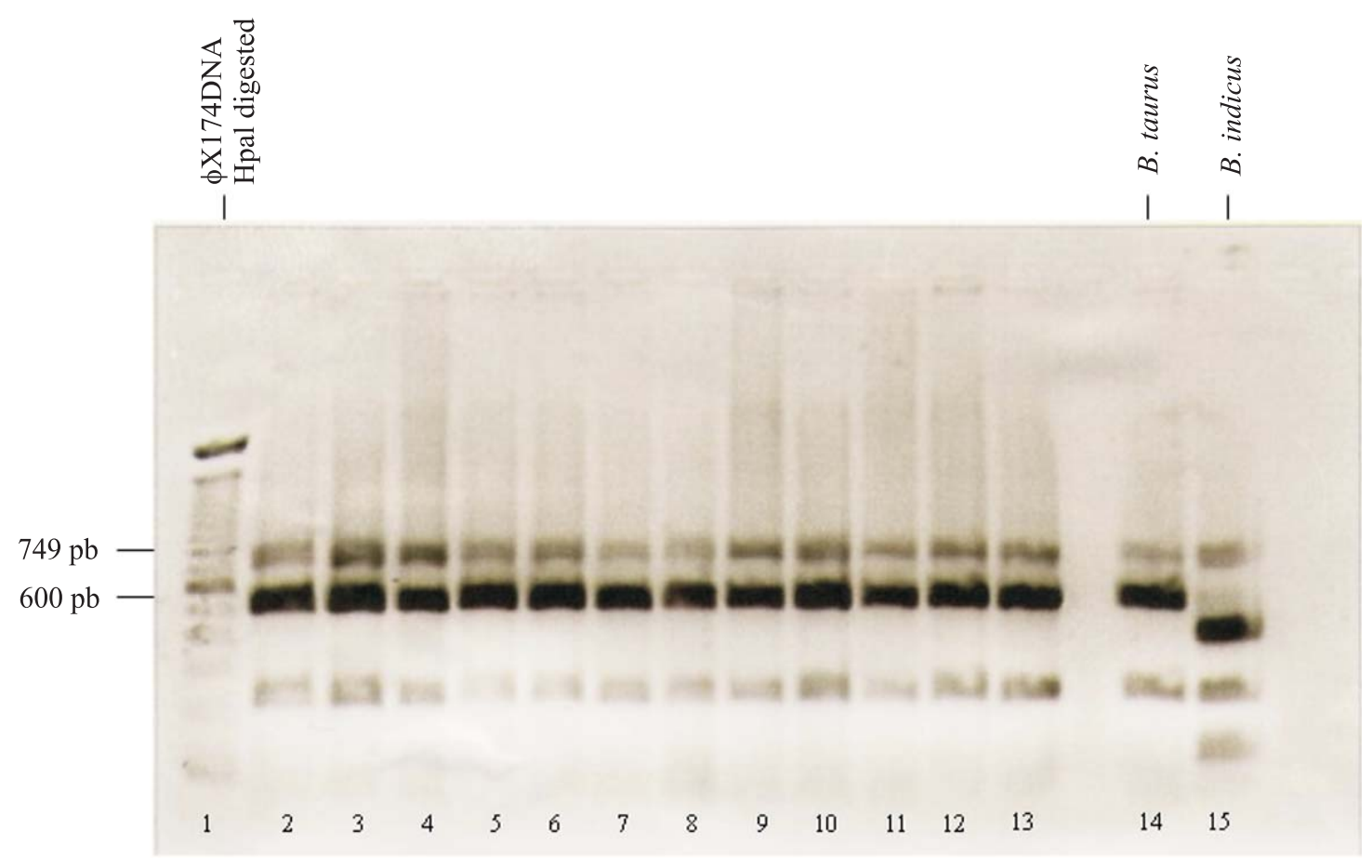

Figure 3. Sample digestion gel. Well $n \underline{0} 1$ is the 100 bp DNA Ladder (Invitrogen). The digested fragment is located around the mark $600 \mathrm{bp}$. From the $2^{\text {nd }}$ to the $13^{\text {th }}$ wells are the animal samples. The $14^{\text {th }}$ well is the B. taurus standard, showing two fragments (one restriction site), and the $15^{\text {th }}$ well is the $B$. indicus standard, with three fragments (two restriction sites). All samples displayed two bands, indicating that the mtDNA is of the $B$. taurus type. It can be seen that the fragments were not completely digested, as the 749 bp band remained over the fragments. 
Loftus et al. (1994) studied the origin of the African breeds using mtDNA. Their results showed that all African and European breeds belong to one lineage, and the Indian breeds to another. Thus, even African animals, which had a zebuine $\mathrm{Y}$ chromosome descended from taurine matriarchs, suggesting a crossed origin.

\section{Conclusions}

1. The karyotype of Pantaneiro bovines, regarding to the Y chromosome, presents a dimorphism (acrocentric and submetacentric); most of them have an acrocentric $\mathrm{Y}$, which is typical for the subspecies Bos taurus indicus.

2. All animals present Bos taurus taurus mtDNA.

3. Since Bos taurus taurus breed descends from Iberian animals, the acrocentric Y chromosome of some animals is indicative of Zebu breed contamination.

\section{Acknowledgements}

ToAnderson Oliveira do Carmo, Daniel Inêz dos Santos Filho, from UFMG, and Christina Ramires Ferreira, from Unesp at Jaboticabal, SP, for technical collaboration; to Capes, to Fundect and CNPq, for financial support granted.

\section{References}

AMBASUDHAN, R.; SINGH, K.; AGARWAL, J.K.; SINGH, S.K.; KHANNA, A.; SAH, R.K.; SINGH, I.; RAMAN, R. Idiopathic cases of male infertility from a region in India show low incidence of Y-chromosome microdeletion. Journal of Biosciences, v.28, p.605612, 2003.

BRITTO, C.M.C. Polimorfismo do cromossomo Y no plantel de gado Pé-duro na Embrapa/PI. 1995. 86p. Tese (Doutorado) Universidade Estadual de Campinas, Campinas.

BRITTO, C.M.C.; MELLO, M.L.S. Morphological dimorphism in the Y chromosome of "Pé-duro" cattle in the Brazilian state of Piauí. Genetics and Molecular Biology, v.22, p.369-373, 1999.

CARVALHO, T.B.; PEREIRA, J.C.C.; PINHEIRO, L.E.L. Avaliação de algumas características ponderais em rebanho Caracu com cromossomo Y heteromórfico. Arquivo Brasileiro de Medicina Veterinária e Zootecnia, v.46, p.271-278, 1994.

DI MEO, G.P.; PERUCATTI, A.; FLORIOT, S.; INCARNATO, D.; RULLO, R.; CAPUTI-JAMBRENGHI, A.; FERRETTI, L.; VONGHIA, G.; CRIBIU, E.; EGGEN, A.; IANNUZZI, L. Chromosome evolution and improved cytogenetic maps of the $\mathrm{Y}$ chromosome in cattle, Zebu, River buffalo, sheep and goat. Chromosome Research, v.13, p.349-355, 2005.
EGITO, A.A.; MARIANTE, A.S.; ALBUQUERQUE, M.S.M. Programa brasileiro de conservação de recursos genéticos animais. Archivos de Zootecnia, v.51, p.39-52, 2002.

EPSTEIN, $\mathrm{H}$. The origin of the domestic animals of Africa. New York: Africana Pub. Corp., 1971. 2v.

EPSTEIN, H.; MASON, I.L. Cattle. In: MASON, I.L. Evolution of domesticated animals. London; New York: Longman, 1984. p.627.

FORESTA, C.; FERLIN, A.; MORO, E.; MARIN, P.; ROSSI, A.; SCANDELLARI, C. Microdeletion of chromosome $\mathrm{Y}$ in male infertility: role of the DAZ gene. Annali Italiani di Medicina Interna, v.16, p.82-92, 2001.

FRISCH, J.E.; DRINKWATER, R.; HARRISON, B.; JOHNSON, S. Classification of the Southern African Sanga and East African shorthorned Zebu. Animal Genetics, v.28, p.77-83, 1997.

GIOVAMBATTISTA, G.; RIPOLI, M.V.; DE LUCA, J.C.; MIROL, P.M.; LIRÓN, J.P.; DULOUT, F.N. Male-mediated introgression of Bos indicus genes into Argentine and Bolivian Creole cattle breeds. Animal Genetics, v.31, p.302-305, 2000.

GOLDAMMER, T.; BRUNNER, R.M.; SCHWERIN, M. Comparative analysis of $\mathrm{Y}$ chromosome structure in Bos taurus and Bos indicus by FISH using region-specific, microdissected, and locusspecific DNA probes. Cytogenetics and Cell Genetics, v.77, p.238-241, 1997.

HANOTTE, O.; TAWAH, C.L.; BRADLEY, D.G.; OKAMO, M.; VERJEE, Y.; OCHIENG, J.; REGE, J.E.O. Geographic distribution and frequency of a taurine Bos taurus and an indicine Bos indicus $\mathrm{Y}$ specific allele amongst Sub-Saharan African cattle breeds. Molecular Ecology, v.9, p.387-396, 2000.

IANNUZZI, L.; DI MEO, G.P.; PERUCATTI, A.; EGGEN, A.; INCARNATO, D.; SARUBBI, F.; CRIBIU, E. A pericentric inversion in the cattle $\mathrm{Y}$ chromosome. Cytogenetics and Cell Genetics, v.94, p.202-205, 2001.

JASZCZAK, K.; PARADA, R.; SLONIEWSKI, K. Two morphologic forms of chromosome Y in Piedmontese cattle. Animal Science Papers and Reports, v.16, p.5-11, 1998.

JORGE, W. Chromosome study of some breeds of cattle. Caryologia, v.27, p.325-329, 1974

LIU, W.S.; BEATTIE, C.W.; LEÓN, F.A.P. de. Bovine Y chromosome microsatellite polymorphisms. Cytogenetic and Genome Research, v.102, p.53-58, 2003.

LIU, W.S.; MARIANI, P.; BEATTIE, C.W.; ALEXANDER, L.J.; LEÓN, F.A.P. de. A radiation hybrid map for the bovine $Y$ Chromosome. Mammalian Genome, v.13, p.320-326, 2002.

LOFTUS, R.T.; MacHUGH, D.E.; NGERE, L.O.; BALAIN, D.S.; BADI, A.M.; BRADLEY, D.G.; CUNNINGHAM, E.P. Mitochondrial genetic variation in European, African and Indian cattle populations. Animal Genetics, v.25, p.265-271, 1994.

MAZZA, M.C.M.; MAZZA, C.A.S.; SERENO, J.R.B.; SANTOS, S.A.; PELLEGRIN, A.O. Etnobiologia e conservação do bovino Pantaneiro. 1.ed. Corumbá: Embrapa-SPI, 1994. 61p.

MEGHEN, C.; MacHUGH, D.E.; BRADLEY, D.G. Genetic characterization and West African cattle. World Animal Review, v.78, p.59-66, 1994. 
MEIRELLES, F.V.; ROSA, A.J.M.; LOBO, R.B.; GARCIA, J.M.; SMITH, L.C.; DUARTE, F.A.M. Is the American Zebu really Bos indicus? Genetics and Molecular Biology, v.22, p.543-546, 1999.

MILLER, S.A.; DYKES, D.D.; POLESKY, H.F. A simple salting out procedure for extracting DNA from human nucleated cells. Nucleic Acids Research, v.16, p.1215, 1988.

SERRANO, G.M.; EGITO, A.A.; McMANUS, C.; MARIANTE, A.S. Genetic diversity and population structure of Brazilian native bovine breeds. Pesquisa Agropecuária Brasileira, v.39, p.543549, 2004.

WATANABE, T.; MASANGKAY, J.S.; WAKANA, S.; SAITOU, N.; TOMITA, T. Mitochondrial DNA polymorphism in native Philippine cattle based on restriction endonuclease cleavage patterns. Biochemical Genetics, v.27, p.431-438, 1989.

XIN, Y.R.; LIN, C.C. Chromosome study on some local breeds of Chinese yellow cattle. Scientia Agricultura Sinica, v.26, p.61-67, 1993.

$\overline{\text { Received on January 21, } 2006 \text { and accepted on July 25, } 2006}$ 